\title{
Who do you want: Barabbas or Jesus? Power and empowerment in theological education
}

\author{
Hendriks, H Jurgens \\ Stellenbosch University ${ }^{1}$ \\ hjh@sun.ac.za
}

\begin{abstract}
The article deals with theological education and leadership and questions the way power and empowerment functions in the church. It argues that theologically we follow the Barabbas choice and reject Jesus by not choosing the way of the cross and weakness. Our true identity needs to be, in following Philippians 2 and other passages, cruciform kenotic. The implications of such an identity for theological education and leadership are then put forward.
\end{abstract}

Keywords

Leadership, theological education, Africa, cruciform-kenotic, discipleship, power, downward empowerment, weakness

\section{Introduction}

The choice of the crowd on that Passover when Jesus was tried and crucified may not be as farfetched as most Christians view it today. It is our default (or natural) choice based on our default value system, which is integrally linked to power and empowerment. In this presentation I will analyse the choice of the crowds and the values that support it and apply it to the concept of power. The concept of power will then be analysed from a biblical point of view focussing on the way Jesus Christ used power. The biblical concept of power and empowerment serves as an acid test that can and should be applied to Christian life and institutions, specifically so to theological education and leadership development. The second part of the

1 The article was presented as a paper at the Theological Education in Africa conferences in Jos, Nigeria (June 2015) and Kampala, Uganda (August 2015). 
article will look critically at theological education and leadership using the biblical principles of the first part of the article to scrutinize it.

\section{The choice between Barabbas and Jesus}

The gospels all tell the dramatic story of how Jesus was put to trail before the Roman governor Pontius Pilate. The chief priests and the elders tried Jesus and decided that he deserved the death penalty because of what was in their eyes blasphemy. Jesus acknowledged to being the Son of God, the Christ or Messiah. However, the Jews did not have the power to confer a death sentence, so Jesus was taken to the Roman governor to be judged. A new set of evidence was presented because Roman law does not allow the death penalty for Jesus's claim to be the Christ. The drama outside Pontius Pilate's palace is well known. Pilate knew Jesus was not guilty. He tried to set Him free but the chief priests and elders played their cards well and when Pilate realized that the whole drama might have repercussions in Rome before the emperor, he tried his last option. Matthew's account reads (Mt 27):

20 Now the chief priests and the elders persuaded the crowds to ask for Barabbas and to have Jesus killed. 21 The governor again said to them, "Which of the two do you want me to release for you?" And they said, "Barabbas." 22 Pilate said to them, "Then what should I do with Jesus who is called the Messiah?" All of them said, "Let him be crucified!" 23 Then he asked, "Why, what evil has he done?" But they shouted all the more, "Let him be crucified!" 24 So when Pilate saw that he could do nothing, but rather that a riot was beginning, he took some water and washed his hands before the crowd, saying, "I am innocent of this man's blood; see to it yourselves." 25 Then the people as a whole answered, "His blood be on us and on our children!" 26 So he released Barabbas for them; and after flogging Jesus, he handed him over to be crucified. ${ }^{2}$

Pilate asked the crowd to choose between a popular hero and a suffering servant. However, influenced by the chief priests and elders, the religious

2 Biblical quotations are from: The Holy Bible: New Revised Standard Version. Nashville: Thomas Nelson Publishers. 1989, S. 
leadership of the day, the die was cast and Jesus was crucified. Preferring Barabbas is humanity's default choice. The type of power symbolized by the two persons is direct opposites representing two conflicting value systems. ${ }^{3}$

From John's account of that crucial Friday an additional hermeneutical lens should be applied. The choice is between the truth and falsehood (Jn 18).

${ }^{36}$ Jesus said, "My kingdom is not of this world. If it were, my servants would fight to prevent my arrest by the Jews. But now my kingdom is from another place." 37 "You are a king, then!" said Pilate. Jesus answered, "You are right in saying I am a king. In fact, for this reason I was born, and for this I came into the world, to testify to the truth. Everyone on the side of truth listens to me." 38 "What is truth?" Pilate asked. With this he went out again to the Jews and said, "I find no basis for a charge against him.

Barabbas and Jesus represent more than a popular hero and a suffering servant. They represent two kingdoms, two sets of radically different values. The kingdom that Barabbas represented was based on the dream and ideology of an Israelite kingdom where the Jews will be victorious and in command of their own country and destiny. He was a hero because he fought and killed on behalf of this kingdom, something the crowd appreciated because they were opposed to the Roman emperor and empire that represented a similar but opposing kingdom. The Jews claimed that their ideological kingdom was the one God promised. Pilate listened to Jesus and realized that the kingdom that Jesus represented was something different, something spiritual and in his view of no consequence to the Emperor in Rome. He therefore rejected the charges of the chief priests and elders. In his opinion Jesus was clearly innocent.

In John (14:6), Jesus told his disciples: "I am the way, and the truth, and the life. No one comes to the Father except through me." At stake here are more than two radically opposing value systems. On a deeper level the choice was between two views on power and identity. Jesus claimed that he in person represents the truth, the way and the life, the Kingdom of God.

3 The 1910 World Missionary Conference at Edinburgh discussed the two realms or spheres of power as one of its eight commissions. Tinyiko Maluleke's (2010:204216) discussion of the theme "Missions and governments" is a worthwhile read as it highlights the biblical theme from a $21^{\text {st }}$ century perspective. 
The best key to understand the value systems at stake is to look at identity. Jesus did not hide his identity. He was a King and he represented the Kingdom of his Father. As such he claimed that what he said and represented is the truth, the way and the life. His servants won't fight the way Barabbas, the chief priests and elders did. His kingdom was different. As such it has different values and its power is different.

Christian identity is about the truth, the way and life in Christ. Our aim is to try to understand what the implications of Christian identity are for theological education and leadership.

The first remark is the obvious one, namely that the Israelite and Roman kingdoms were at loggerheads. The identity of these kingdoms was ideological, military, and physical in nature. They fought one another, they despised one another and the ultimate form of power that decided the outcome of who is in charge of affairs is physical military power. Barabbas physically fought against the Romans and thus was regarded as a hero. Jesus explained to Pilate that the kingdom of God was something different. No physical fighting! It was, for lack of better words, a spiritual kingdom with a completely different set of values in which power works completely differently. Jesus' claims that he represents and is the truth meant that the kingdom and values he represents are trustworthy. Pilate simply shrugged when he heard the claim about the truth.

Believing in Jesus and becoming like Jesus is not a natural choice even for religious leaders. The Jewish leaders, the crowd and the Roman governor illustrated it. The power they held unto and the values that operated on that Friday are those of all earthly kingdoms. Jesus, however, is the way to the Father. He was crucified and resurrected. He is the illustration and explanation of what authentic Christian love and identity is, implies as well as what is expected from a leader.

\section{Phillipians 2}

The words of Jesus to Pilate that his kingdom is of another place, is explained in Philippians 2. The contrast between the Roman Empire as the archetypical worldly kingdom and the Kingdom of God is stark and clear in this passage. 
Act 16 relates Paul's visit to Philippi. Verse 12: “... we traveled to Philippi, a Roman colony and the leading city of that district of Macedonia. And we stayed there several days." They stayed with Lydia, a dealer in purple cloth, and proclaimed the gospel. Lydia and her household were baptized. When they healed a slave girl that earned her owners a lot of money by fortune telling, the owners were angry and laid a charge against Paul and Silas. "They brought them before the magistrates and said, 'These men are Jews, and are throwing our city into an uproar21 by advocating customs unlawful for us Romans to accept or practice." The crowds joined the uproar against Paul and Silas who were stripped, flogged and thrown in prison. The story of their prayers and singing in prison, the violent earthquake, and the jailor who became a follower of Jesus and who was baptized with his family is well known. The fascinating part that gives us a clue as to the opposing value systems that are at stake then follows:

${ }^{35}$ When it was daylight, the magistrates sent their officers to the jailer with the order: "Release those men." ${ }^{36}$ The jailer told Paul, "The magistrates have ordered that you and Silas be released. Now you can leave. Go in peace." ${ }^{37}$ But Paul said to the officers: "They beat us publicly without a trial, even though we are Roman citizens, and threw us into prison. And now do they want to get rid of us quietly? No! Let them come themselves and escort us out." ${ }^{38}$ The officers reported this to the magistrates, and when they heard that Paul and Silas were Roman citizens, they were alarmed. ${ }^{39}$ They came to appease them and escorted them from the prison, requesting them to leave the city.

Why did Paul and Silas not mention their Roman citizenship when they were dragged to the magistrate and flogged? It would have stopped the beating and saved them from a night in jail! The answer is that they were following the example of Jesus in his meeting with Pilate (Hellerman 2013:173). Paul explains the counterintuitive value system in Philippians 2. The use of power in the kingdoms of earth and the Kingdom of heaven differs. Jesus could have called on the angels, could perform a miracle; Paul could have called on the Roman juridical system, but did not. Power and empowerment of a different order based on totally opposing values systems that fundamentally goes back to opposing identities are here at stake. 
Joseph Hellerman (2013) helped me to understand the Roman context and culture in his work on Philippians. Paul's letter illustrates the opposing value systems, especially in the terminology he uses. Hellerman describes (2013:24-28) the social stratification and pecking order in the Roman world with its elites (senators, equestrians and decurions totalling about 1 million people of the population of the Roman Empire) and the non-elites (freeborn, freedmen and slaves, totalling about 49 million) in detail. It was apartheid on a grand scale, the archetypical rich and poor distinction (see James 2:56). It is funny but also scary to realize how social classes were distinguished by language, by seating arrangements, the way you dress (gowns and titles amongst others!) thus spelling out the nuanced demarcation lines between the different classes. There is nothing new under the sun. In Roman society nothing played a more important role than status and honour. Hellerman (2013:66):

Roman elites competed with one another for honor on the battlefield, and they competed with one another for honor in the political arena. On the home front this "struggle for reputation" centered around the honorific offices that constituted Rome's cursus honorum, or "race for honors."

However, in Philippians Paul calls on the congregation to live a life worthy of the gospel (1:27) meaning: a life different from the race for power, honour and glory or upward mobility (Nouwen, 2007). He reminds them in 3:20 that "... our citizenship is in heaven." The church is a fellowship, a family, a voluntary association in which downward empowerment is the ideal. $\mathrm{He}$ begins his letter with (Phil 1:1):

Paul and Timothy, servants (douloi, slaves) of Christ Jesus, to all the saints in Christ Jesus at Philippi, together with the overseers and deacons. ${ }^{4}$

Paul and Timothy: slaves! The congregation: saints! Those who were trained and appointed by Paul and others: Overseers and deacons! The

4 Paul usually refers to himself as "apostle" but only in Philippians and Romans, cities where the Roman honour-oriented culture of the Empire was rife, did he refer to himself as "slave." When referring to the Philippian leaders he uses the word deacons since it already imply service but he refrains from using bishops (presbuterio) when referring to the elders and uses a more neutral word: overseers (episkopos). 
hierarchical pyramid is turned upside down. It is a different value system, a different identity that is at stake here. The crowds in Philippi realized this and told the magistrate in Philippi that they are "advocating customs unlawful for us Romans to accept or practice". When Paul and Silas moved on from Philippi to Thessalonica the same drama unfolded and once again the crowds were used to leverage the default option. These were their words (Acts 17:6):

These men who have caused trouble all over the world have now come here, ${ }^{7}$ and Jason has welcomed them into his house. They are all defying Caesar's decrees, saying that there is another king, one called Jesus.

Paul's master story (Gorman 2009:13) the core theology of Christian identity and the true meaning of power and empowerment is described in Philippians 2. In the Message translation the heading is: "He took on the status of a slave."

Phil 2:1-4: If you've gotten anything at all out of following Christ, if his love has made any difference in your life, if being in a community of the Spirit means anything to you, if you have a heart, if you care - then do me a favor: Agree with each other, love each other, be deep-spirited friends. Don't push your way to the front; don't sweet-talk your way to the top. Put yourself aside, and help others get ahead. Don't be obsessed with getting your own advantage. Forget yourselves long enough to lend a helping hand. 5-8 Think of yourselves the way Christ Jesus thought of himself. He had equal status with God but didn't think so much of himself that he had to cling to the advantages of that status no matter what. Not at all. When the time came, he set aside the privileges of deity and took on the status of a slave, became human! Having become human, he stayed human. It was an incredibly humbling process. He didn't claim special privileges. Instead, he lived a selfless, obedient life and then died a selfless, obedient death - and the worst kind of death at that - a crucifixion. ${ }^{9-11}$ Because of that obedience, God lifted him high and honored him far beyond anyone or anything, ever, so that all created beings in heaven and on earth - even those long ago dead and buried - will bow in worship before this Jesus 
Christ, and call out in praise that he is the Master of all, to the glorious honor of God the Father. ${ }^{5}$

The contrast between the two kingdoms should be clear, the opposing value systems unmistakable. In the world power and empowerment are sought in a vortex of upward empowerment and honour culminating in the position of the emperor.

In Jesus Christ one sees the radical opposite. I am following Gorman (2009:25) in explaining the "counterintuitive narrative identity of Christ and God".

Against the background of the typical cultural race for upward mobility, verses 1-4 explain the love and support that Paul expects from a Christian community. It is about abandoning honour and a rat race for power and prestige. It is about following the example of Christ, which is then explained in 5-8 (Gorman 2009:25):

Phil 2:6-8 reveals the narrative identity of the Messiah Jesus as one who possessed equality with God ... did not exploit it for selfish advantage ... but, like a slave, emptied himself in incarnation and humbled himself obediently ... such that the result was death death on a cross.... Christ's divinity, and thus divinity itself, is being narratively defined as kenotic and cruciform in character.

What we read here is truly about a Kingdom that is "from another place," the opposite of the Roman, typical human one. I follow Gorman (2009:2736) in the theological interpretation of this passage. Genesis 1: 26-28 accounts how the Trinitarian God made humankind to his image and likeness. The implications of being made to God's image and likeness are explained in Isaiah's servant songs (42:1-9; 49:1-13; 50:4-9; 52:13-53:12). In Philipians 2 Christ illustrates it. God is cruciform kenotic; that is God's identity. Cruciform refers to the cross and kenotic is a Greek word that means emptying. It means God, in Christ, humbled himself, emptied himself of all status ${ }^{6}$, safe places and physical power to selflessly reach out

5 Peterson, Eugene H 2002. The Message: The Bible in Contemporary Language. Colorado Springs, Colorado: NavPress.

6 The issue here is that Christ emptied himself of all status, not ontology or essential nature (Hellerman 2013:145) 
to the lowest levels of human existence. In an act of downward mobility ${ }^{7}$ he never used physical force or power in bringing the gospel to all, even to slaves and in doing so he was crucified. The gospel of mercy and love, of downward empowerment, caused havoc in the worldly empires simply because it contradicts the value system of this world. Leaders and crowds can't take it. They prefer to crucify it or send it away!

The cruciform kenotic Christ illustrated a completely different value system. He entered our world and showed us the way his power should be used i.e. in serving the other, identifying with the poor, the weak and the powerless. ${ }^{8}$ Dying on a cursed cross was the final and authentic illustration of forfeiting all earthly power in selfless identification with the other. This is divine identity. Through the power and work of the Holy Spirit a cruciform kenotic identity gets enacted. Paul and Silas followed Christ in that they did not use their Roman citizenship as an excuse to forfeit a terrible beating. They identified with the realities of those at the bottom of the class system and illustrated love and deep-spirited friendship that forgot themselves long enough to lend a helping hand to all the peoples, elites and non-elites, in Philippi. ${ }^{9}$

God is not a God of power and weakness; God is a God of power in weakness. Thus weakness is the cue to understand that power is redefined here. It is the power of love, the embrace of grace and mercy, the emptying

7 See the blogspot http://experimentaltheology.blogspot.com/2013/03/downward-mobility.html about downward mobility as Christ's example.

8 This is the cry of the liberation theology. Listen to Gutiérrez (1988:171) "If there is no friendship with them and no sharing of the life of the poor, then there is no authentic commitment to liberation, because love exists only among equals." I am not sure that the followers of liberation theology stick to this plea "after" liberation. When in power, the plea is easily transformed into entitlement.

9 Pope Francis (2015) uses the argument that he calls "integral ecology" (\$137) and then explains (\$208): “We are always capable of going out of ourselves towards the other. Unless we do this, other creatures will not be recognized for their true worth; we are unconcerned about caring for things for the sake of others; we fail to set limits on ourselves in order to avoid the suffering of others or the deterioration of our surroundings. Disinterested concern for others, and the rejection of every form of selfcenteredness and self-absorption, are essential if we truly wish to care for our brothers and sisters and for the natural environment. These attitudes also attune us to the moral imperative of assessing the impact of our every action and personal decision on the world around us. If we can overcome individualism, we will truly be able to develop a different lifestyle and bring about significant changes in society." 
of self, the upbuilding of the other, which means an empowerment of the other. Christ lived it; he illustrated the way and the truth thereof. Being "in Christ" means that his image and likeness takes shape in the way we live and act and thus become part of this "another Kingdom." It is not our natural choice or our default to choose this way of life. It needs a conversion experience empowered by the Holy Spirit.

The power of upward mobility and honour seeking is a constant temptation to the church. Hellerman in his study on Philippians and the Roman culture remarks (2013:75-76):

The Philippian church, too, finally caved in to such pressures, long after the apostle Paul had left the scene ... The process of accommodation to the values of the dominant culture continued unabated for the next several centuries. By the time Christianity became the state-sponsored religion in the fourth century A.D., the ascending list of honorific titles in the Christian church pretty much mirrored in principle the cursus honorum of the post-Constantinian Roman imperial court."10

NT Wright's (1986:345-346) article on Philipians 2:5-11 concluded in these words:

The pre-existent son regarded equality with God not as excusing him from the task of (redemptive) suffering and death, but actually as uniquely qualifying him for that vocation ... The real humiliation of the incarnation and the cross is that one who was himself God, and who never during the whole process stopped being God, could embrace such a vocation. The real theological emphasis of the hymn, therefore, is not simply a new view of Jesus. It is a new understanding of God. Against the age-old attempts of human beings to make God in their own (arrogant, self-glorifying) image, Calvary reveals the truth about what it means to be God. Underneath this is the conclusion, all-important in present Christological debate: incarnation and even crucifixion are to be seen as appropriate vehicles for the dynamic self-revelation of God.

10 A 2015 Nigerian variation on the theme is: "the Prelate and Moderator of the General Assembly, His Eminence, Most Rev Prof Dr ..." 
The age-old human choice is indeed Barabbas. Following Jesus is "out of this world!"

Marva Dawn (2001:45) is a must-read to understand power in weakness as it operates in the Bible. She says that the "tabernacling" (dwelling) of God that takes place in our weakness creates the openness for the power of the Holy Spirit to operate through us. "Dying to the law, dying to our selves, dying to our attempts to use our own power to accomplish God's purposes are all part of the gospel of grace - the end of ourselves and therefore the possibilities of new life with Christ, in vital union to him." This is one key perspective on Christian identity. The honour and exaltation of Christ and Christians lie in being weak (staying weak), in permanently serving the other and not the self as such allowing the power of the Holy Spirit to function in bringing about peace and the Kingdom of God.

\section{Power and empowerment in theological education}

This brings us to the third part of the presentation in which we ask: "Who do you choose in theological education: Barabbas or Jesus?" How do we disciple future church leadership?

The question up front is about the use of power and about who is exalted (the status / honour issue). What is power and how does empowerment take place in education? Is it possible to pinpoint the characteristics of the opposing systems with regard to theological education? ${ }^{11}$

The best place to discern the difference between the two systems does not lie, in the first place, on a rational or confessional level. The hermeneutical key to choosing Jesus lays in scrutinizing our identity and in purposefully choosing to follow Jesus on an Abrahamic journey to this "other Kingdom." The essence of this journey in terms of Paul's Philippian letter chapter 2 boils down to understanding who Christ is and how power and empowerment operates in his Kingdom.

How did Jesus train his disciples? He called (proskaleomai) them to follow (akoloutheo) him, they became disciples (mathetes, learners) that have to

11 For a good overview of views and the state of affairs in theological education, see: Global Survey on Theological Education (GSTE), 2011-2013. http://www.globethics.net/web/ gtl/research/global-survey [Assessed May 2, 2014] 
imitate (mimeomai) his way of life, and mirror his identity. The process of becoming a disciple implies a conversion, being reborn; it is built on believing that Jesus is the Messiah, Lord, the Son of God and it implies following Him on this journey in establishing "another Kingdom." It is a cruciform kenotic happening meaning; an emptying of self and a selfcentred life and a willingness to give your life in service to God and to others. It is about empowering others. It is about the missio Dei.

Who do you choose? Another way to help us to understand the choice between Barabbas and Jesus is to look at the temptations that confronted the first and second Adam. In Genesis 3 one sees the personal temptation to embrace the kind of power that makes you a king unto yourself in your own paradise. Genesis 11 gives the corporate version of the same temptation, i.e. the ideology of building a tower and a city where you can be a law unto yourself. This is the classical apartheid dream that one finds in thousands of variations in history and today.

Christ was tempted in a more nuanced way (Mt 4:1-11; Lk 4:1-13). I am following Henri Nouwen's classic In the name of Jesus: Reflections on Christian leadership (1989). The three basic temptations, one can call it primordial temptations, are temptations of the flesh (the physical stuff like food, sex, narcissism); temptations focused on honour (Nouwen called the second temptation "to be spectacular") and then the final one about power, about being an emperor or king or lord in this world). Each of these temptations has its own configuration in theological education and it does not take much imagination to discover it.

To understand the complexity of how difficult it is to choose counterintuitively for Jesus and not Barabbas, the remainder of the presentation will deal with three issues: Firstly we will highlight the difficulty of the Barabbas-Jesus choice by looking at how Jesus handled the situation when his disciples lapped into the Barabbas-default. Secondly, I will summarise a classic expression of how Jesus taught the twelve and then, in conclusion, we will ask a number of very critical questions about theological education, as we know it.

The narrative of Jesus' training of the disciples shows how difficult it is for pastors and theological educators to consistently follow the cruciform-kenotic way of weakness. We default back to the Barabbas choice. Jesus noticed this 
among his disciples. When they asked him: "Who is the greatest in the kingdom of heaven?" Jesus answered: "I tell you the truth, unless you change and become like little children, you will never enter the kingdom of heaven" (Mt 18:1-3). The issue was not settled. The mother of two of the disciples came to Jesus and requested that her sons may be seated at his right and left hand in the "other kingdom." Upon hearing this request the remaining ten disciples were indignant. Jesus called them together and said (Mt 20):

You know that the rulers of the Gentiles lord it over them, and their high officials exercise authority over them. ${ }^{26}$ Not so with you. Instead, whoever wants to become great among you must be your servant (diakonos), ${ }^{27}$ and whoever wants to be first must be your slave (doulos $-{ }^{28}$ just as the Son of Man did not come to be served, but to serve, and to give his life as a ransom for many.

In Matthew 23 Jesus talked about authority and use of power by the teachers of the law and the Pharisees - the theological educators of his day. He mentioned that they don't walk what they talk and that they burden people with legalistic ordinances that they themselves don't follow while they like to sit in special seats and be called honour-laden titles. Jesus then said (Mt 23:8-11):

But you are not to be called 'Rabbi,' for you have only one Master and you are all brothers. ${ }^{9}$ And do not call anyone on earth 'father,' for you have one Father, and he is in heaven. ${ }^{10}$ Nor are you to be called 'teacher,' for you have one Teacher, the Christ. ${ }^{11}$ The greatest among you will be your servant. ${ }^{12}$ For whoever exalts himself will be humbled, and whoever humbles himself will be exalted.

The way in which Jesus then condemned the theological fraternity of his day is quite scary (Mt 23:13-36). The difference between the two kingdoms, the Barabbas-Jesus contrast is exceedingly clear. Jesus walked his talk. One outstanding example was when Jesus washed the feet of his disciples (Jn 13) and after that how he coached them on what is about to happen and how they should deal with it (Jn 14-17). The culmination of his cruciformkenosis was a view hours away.

The question that we as pastors, leaders and theological educators must ask ourselves is whether we are free from falling in the Barabbas trap and whether there is a resemblance between our way of training our students 
in seminary or leaders in congregations. I am going to use the epochal little book published by Robert Coleman in 1963, still in print, which sold more than 3.5 million copies to give us a glimpse of the strategy that Jesus followed. I will be quoting from the 1989 edition of The Master Plan of Evangelism. The goal is to ask us as Christian leaders and educators if these principles are still at stake in theological education. Coleman summarized the training of the twelve in eight principles:

1. Selection: Jesus did not follow a program nor taught a course but he selected 12 men to follow him. There were women too, but cultural curtains prevent us from seeing their calling and ministry as clearly as that of the 12 disciples. ${ }^{12}$

2. Association: Jesus spent more time with the twelve than with any other single group or groups together. They were called to follow him. They were taught by simply following Jesus being in a personal relationship with him. Spiritually they were like his covenanted children.

3. Consecration: Jesus required obedience, loyalty, and sacrifice. "There was a cross in it - the willing denial of self for others (Mk 8:34-38; 10:3245; Mt 16:24-26; 20:17-28; ..." (Coleman 1989:51). Jesus demonstrated it in his life and on the cross. Discipleship is not about a doctrine or an examination; it was about a Person and following that Person.

4. Impartation: Jesus gave himself away. Love is about giving yourself to the world; John 3:16. The conversion from self to the other is the work of the Holy Spirit. The Spirit baptized Christ and Christ explained the work of the Spirit to his disciples (Jn 14, 16). He told his disciples to wait for the outpouring of the Holy Spirit that will empower them towards impartation or kenosis-like emptying of self (Acts 1:4-8).

5. Demonstration. Explanation should be a minor part in teaching, demonstration is the essential part. The disciples observed Jesus in prayer, in his use of Scripture, in his preaching and teaching to the

12 Paul summarized the principle here at stake well in Ephesians 4:1-2: " ${ }_{11}$ It was he who gave some to be apostles, some to be prophets, some to be evangelists, and some to be pastors and teachers, ${ }^{12}$ to prepare God's people for works of service, so that the body of Christ may be built up ${ }^{13}$ until we all reach unity in the faith and in the knowledge of the Son of God and become mature, attaining to the whole measure of the fullness of Christ." 
crowds and in his pastoral work. He spent quality time with them explaining the why and how of what they saw him doing.

6. Delegation: from the very beginning the fishermen knew that they were to become fishers of men, labourers of a harvest and ever so gradually Jesus challenged them to proclaim the gospel like he did (Lk 9, 10, Mt 28:16-20). They had to go and proclaim the coming of the Messiah and the Kingdom of God. Being representatives of Christ was their identity!

7. Supervision will probably today be called mentorship. It was on the job training par excellence with discussions about theory and practice. He helped them to grow towards maturity; he answered their questions and managed their conflict. Think about Peter and his betrayal and how Jesus guided him back into the fold (Jn 18:15-27; 21:20-25).

8. Reproduction: Jesus explained in passages like John 15 with the parable of the vine and the branches that his followers should mirror his likeness. The church is built on Peter's confession "You are the Christ, the Son of the living God." The well-known Great Commission of Matthew 28:16-20 is basically "Go and make disciples ..." etc. Making disciples means making followers of Christ, people in whom Christ is alive and present. It means following Christ in training disciples the way he did it, reproducing his identity. All of this happens in and through the power of the Holy Spirit.

The last part of this article wants to look critically at theological education, as we know it today. ${ }^{13} \mathrm{I}$ want to ask some questions in the light of the discussion up to now:

13 This article on theological education and leadership follows a biblical-theological line. However, the "Handbook for Theological Education in Africa" (Phiri \& Werner 2013) has been a constant conversational partner in the quest for transformation in theological education. The Handbook's 113 articles over 1110 pages are an indispensable library to our topic. It is difficult to mention certain articles, but to get an introduction one can mention the chapters by Njoroge (2013:64-69); Gatwa (2013:84-99); Houston (2013:108$116)$ and one with which I really associate: Mugambi (2013:117-125). These are some examples from Part 1 only!

Previous articles by the author that deals with the topic are: Hendriks, HJ 2012. 'Contextualizing theological education in Africa by doing theology in a missional hermeneutic', vol. 2, 8 pages. doi: 10.4102/koers.v77i2.56 http://koersjournal.org.za/index.php/ koers/article/view/56; Hendriks, HJ 2014. Are we wasting theology in our continent? HTS 
1. What is the balance between rational analytic knowledge and the formation of wisdom and maturity in theological training? Have we looked critically at the influence of modernism and the Western educational system on theological education or are we uncritically following it Barabbas-style?

2. Modernism and Western education are overly analytic in character. This can be seen in the typical encyclopaedic nature of our curricula, six main subjects: OT, NT, ST, Church history, Practical Theology and Missiology. Each of these subjects has specialization fields with highly specialized knowledge. Don't we require a much more holistic approach (Tennent 2007:249-274)?

3. The role that titles, special clothing like robes and gowns coupled with the typical academic rat race has in our theological institutions reminds us of the institutions of the Roman Empire and the words Jesus used in describing the theological leadership of his day. Is this not a Barabbas choice? Do we serve by literally washing feet, associating with those that we teach? ${ }^{14}$

4. If we look at the discipleship principles that Jesus followed, we can see that they were thoroughly personal and relational. Is this the case at theological institutions and in congregations? Do we teach by talking or walking? How well do we know our students and how well do they know us? Do we know each other's families, houses, and stories?

SPT Volume 70, Issue 2, 2014 http://www.hts.org.za/index.php/HTS/article/view/2610; Hendriks, HJ 2014. Theological education in Africa: messages from the fringes, Dutch Reformed Theological Journal, 55 No 1\&2, March-July 2014. http://ngtt.journals.ac.za/pub/article/ view/516/536

After the presentation of this paper I met the Provost of JETS in Jos, Nigeria. His book on discipleship gives a very good account of an African view on discipleship. Motty, 2013.

14 In line with Dawn's argument that a theology of weakness pervades (2001:53) the New Testament and the Trinity's "hidden" way for working out God's purposes, illustrated in Christ's suffering and death (2001:47), she puts the following questions to church leadership and a such to theological education (:57):

Why have we turned pastors into successful CEOs instead of shepherds for the weak?

Why do we search for pastors who are handsome, sophisticated, charismatic instead of models of suffering?

Why do our churches adopt practices of business life and its achievement models?

Why do we resort to gimmicks, of what Jacques Ellul calls Technique, instead of practicing an unadulterated handling of the Word?" 
5. How contextual is our training? Jesus addressed the issues and challenges of his day. Their curriculum dealt with the issues with which they were confronted "on the streets and in the houses" of their world. The issues of the day were their programs. Is this the case today? To which extent is our theological training stuck in classrooms and in church buildings? What percentage of our training takes place "out there?"

6. Jesus crossed boundaries and the early church applied the Acts 15 principle (Walls 2002:67-68; 76, 77). Jesus took his disciples to the temple and synagogues, he taught there. But he also took them across so many cultural and traditional (ideological) boundaries that they were constantly exposed to "the other." The Pharisees and teachers of the law were appalled by this and criticized Jesus constantly. Crossing boundaries is the essence of the missio Dei. Acts 15 decreed that we should have converts but not make proselytes. How many theological schools excel in making denominational proselytes? (Walls 2002:68) How many seminaries really cross boundaries with their students?

7. Are we saving souls and dreaming about a far-away heaven or do we understand that the gospel is about the kingdom of God taking shape in this world? Do we understand the missio Dei and that it has to do with everything that happens in this world? The political arena, the ecology, the economy - all these areas are mission fields needing labourers. Do we train accordingly? Are we missional in our theology and training (Guder 2009)?

8. Are we training prophets (Igboin 2012)? Do our churches and theological institutions produce people of the calibre of the OT prophets, people with the image and likeness of Christ whose words fearlessly address the issues of our day?

\section{Conclusion}

Historians describe that the astonishing growth of the church in the first centuries (Stark 1997) after Christ faded away in the fourth and subsequent centuries. It should be a wake-up call to us today. The early church became domesticated by the cultures surrounding it and lost its counter-cultural edge (Walls 2002:34-47). The Barabbas option began to prevail. Institutionalization took place and leadership hierarchies evolved. The clerics-laity divide grew; titles and clothing-splendour followed the 
hierarchical class structures of the day. To become a priest, a pastor, a doctor in theology, a professor teaching theology became something to aspire to because it brings status (honour). Power were instituted at the top of denominational hierarchies and not distributed to the church members as a whole to empower them to be the light of the world and the salt of the earth to their societies.

Are we following Christ in the cruciform-kenotic style pouring our lives into those we serve helping and empowering them to grow and to take up the missio Dei?

Is our preaching and teaching prophetic and fearlessly addressing the ills and corruption of our countries and continent to such an extent that we are willing to put our lives at stake?

To which extent does our theological training accommodate the discipleship principles of the Old and New Testament illustrated by Jesus in the training of the twelve?

When we are gathered as theological educators and church leaders, what is the style of our meetings like?

Are we presenting learned papers and then discussing them in a modernistic debating style, analysing the arguments and quoting from our denominational confessions and systematic theology?

Or are we gathered like the disciples in some upper-room with the women who are serving Jesus? What role does prayer and waiting on the power of the Holy Spirit play?

Who do we choose: Barabbas or Jesus? Nkosi sikelelí Afrika: God bless AfricaMakube njalo: May it be so forever

\section{Bibliography}

Coleman, RE 1989 [1963]. The master plan of evangelism, Old Tappan, Revell.

Dawn, MJ 2001. Powers, weakness, and the tabernacling of God. Grand Rapids: Eerdmans. 
Gatwa, T 2013. The cross-cultural mission: An agenda for theological education in Africa, pp 84-99, in: Phiri, I \& Werner, D (eds.), 2013. Handbook for Theological Education in Africa. Genève: WCC-Cluster.

Global Survey on Theological Education (GSTE), 2011-2013. http://www. globethics.net/web/gtl/research/global-survey [Accessed May 2, 2014]

Gorman, MJ 2009. Inhabitating the cruciform God, kenosis, justification and theosis in Paul's narrative soteriology. Grand Rapids: Eerdmans.

Guder, Darrell 2009. Missio Dei: integrating theological formation for apostolic vocation? Missiology: An international review. Volume XXXVII (1):63-74.

Gutiérrez, G 1988. A Theology of liberation, (15th Anniversary Edition), New York: Orbis.

Hellerman, JH 2013. Embracing shared ministry. Power and status in the early church and why it matters today. Grand Rapids: Kregel.

Hendriks, HJ 2014. Are we wasting theology in our continent? HTS SPT. Volume 70 (2). http://www.hts.org.za/index.php/HTS/article/view/2610

Hendriks, HJ 2012. Contextualizing theological education in Africa by doing theology in a missional hermeneutic. Vol. 2, 8 pages. doi: 10.4102/koers.v77i2.56. http://koersjournal.org.za/index.php/koers/article/view/56

Hendriks, HJ 2014. Theological education in Africa: messages from the fringes. Dutch Reformed Theological Journal. 55(1\&2). http://ngtt.journals. ac.za/pub/article/view/516/536

Houston, B 2013. The future is not what it used to be. Changes and choices facing theological education in Africa. In: Phiri, I \& Werner, D (eds.). Handbook for Theological Education in Africa. Genève: WCC-Cluster. 108-116.

Igboin, B 2012. Religious conflicts in Nigeria: Towards a re-awakening of the prophetic voice. Akungba Akoko: Adekunle Ajasin University Press.

Maluleke, Tinyiko 2010. Christian mission and political power: commission seven revisited. In: Kerr, David A \& Ross, Kenneth R. Edinburgh 2010, mission then and now. Eugene, Oregon: Wipf \& Stock. 204-216. 
Motty, BD 2013. Indigenous Christian discipleship-making. Jos, Nigeria: ECWA productions.

Mugambi, Jesse 2013. The future of theological education in Africa and the challenges it faces. In: Phiri, I \& Werner, D (eds.). Handbook for Theological Education in Africa. Genève: WCC-Cluster. 117-125.

Njoroge, NJ (2013). Ecumenical theological education and the church in Africa today. In: Phiri, I \& Werner, D (eds.). Handbook for Theological Education in Africa. Genève: WCC-Cluster. 64-69.

Nouwen, Henri JM 2002. In the name of Jesus: Reflections on Christian leadership with study guide. New York: Crossroads.

Nouwen, Henri JM 2007. The selfless way of Christ: downward mobility and the spiritual way of Christ. New York: Orbis.

Peterson, Eugene H 2002. The Message: The Bible in Contemporary Language. Colorado Springs: NavPress.

Phiri, I \& Werner, D (eds.) 2013. Handbook for Theological Education in Africa. Genève: WCC-Cluster.

Pope Francis, 24 May 2015, Laudato si, Encyclinal letter of the Holy Father Francis on the care of our common home. Online available at w2.vatican.va/.../papa-francesco_20150524_enciclica-laudato-si.html.

Stark, R 1997. The rise of Christianity. San Francisco: Harper Collins.

Tennent, Timothy C 2007. Theology in the context of World Christianity: how the global church is influencing the way we think about and discuss theology. Grand Rapids: Zondervan.

Walls, Andrew F 1996. The missionary movement in Christian history: Studies in the transmission of faith, Orbis, Maryknoll: New York.

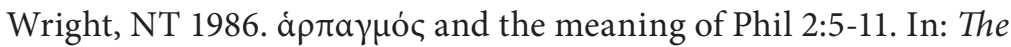
Journal of Theological Studies. Vol 37(2):321-352. 